\title{
The Paleoanthropocene of the Yucatán Peninsula: palynological evidence of environmental change
}

Gerald A. Islebe, Nuria Torrescano-Valle, Alejandro A. Aragón-Moreno, Alejandro A. Vela-Peláez, Mirna Valdez-Hernández

Gerald A. Islebe

gislebe@ecosur.mx

Nuria Torrescano-Valle

Alejandro A. Aragón-Moreno

Alejandro A. Vela-Peláez

Mirna Valdez-Hernández

El Colegio de la Frontera Sur, Herbario,

Departamento Conservación de la Biodiver-

sidad, Avenida Centenario km 5.5, Apartado Postal 424, CP 77014, Chetumal, Quintana

Roo, México.

\begin{abstract}
Human activities have changed and shaped landscape conditions of the Yucatán Peninsula for more than 4000 years. Several paleoecological studies showed the oldest pollen record of corn-based agriculture is from northern Belize, with an estimated age of $3300 \mathrm{BC}$.

Several other studies report maize between 1500 and $3000 \mathrm{BC}$ from northern Guatemala and the Mexican part of the Yucatán Peninsula. After 3500 cal yr BP several paleoecological studies showed a marked tendency to drier climatic conditions. In pollen records, increased drought is expressed as a reduced presence of fossil arboreal pollen. Pollen records with the presence of Zea mays also show other taxa, which are indicators of disturbance in different vegetation types.
\end{abstract}

Keywords: Paleoanthropocene, Holocene, Yucatán Peninsula, fossil pollen, Zea mays.

\section{RESUMEN}

Las actividades humanas han influenciado sobre los paisajes de la península de Yucatán desde más de 4000 años. Varios estudios paleoecológicos muestran actividades de agricultura, el registro polínico más antiguo de maiz (Zea mays $L$.) proviene del norte de Belice, con una edad aproximada de 3300 $B C$. Otros estudios paleoecológicos del norte de Guatemala y de la porción mexicana de la peninsula de Tucatán muestran registros de maíz fósil con rangos de edad desde 1500 a 3000 A.C. La mayoría de los registros muestran una marcada tendencia a condiciones de mayor sequía después de los 3500 A.C. Estas tendencias de sequía se registran como reducción del polen fósil arbóreo. El registro polínico de Z. mayss está acompañado de taxa que indican diferentes grados de perturbación en la vegetación natural.

Palabras clave: Paleoantropoceno, Holoceno, península de Yucatán, polen fósil, Zea mays. 


\section{Introduction}

The Yucatán Peninsula has a long history of human impact and use, starting in the middle Holocene until the present, or Anthropocene. The interaction of human with natural forces has shaped the landscape of the Yucatán Peninsula on different scales and therefore offers a valuable opportunity of understanding past and present sustainability (DeClerk et al., 2010; Douglas et al., 2016; Ford and Nigh, 2016). The term Anthropocene was introduced by Crutzen and Stoermer (2000) to highlight the human influence on the environment and some researchers even proposed the term Palaeoanthropocene as the period of first anthropogenic change until the early industrial revolution (Foley et al., 2013). More specific to the area occupied by Maya culture and their influence on the environment, the term Mayacene was proposed to describe the period for the last 3000 years (Beach et al., 2015).

In this paper we expand the idea of the Paleoanthropocene to the last 4000 years, as human impact on natural resources is evident in southern Mexico and Mesoamerica (Voorhies, 1996; Leyden, 2002) from this environmentally influential period. The human-environment-climate interaction goes back at least 4000 years, when early settlers became established and agriculture began transforming the landscape during the Archaic period. Abandonment of cities is strongly but not exclusively linked to climatic variability (Fedick, 2010; McNeil et al., 2010; Dunning et al., 2012, 2015; McNeil, 2012; Douglas et al., 2016), and several studies have highlighted Maya cultural development related to climatic events and environmental conditions using different proxies like isotope chemistry, sediment geochemistry and pollen (Hodell et al., 1995; Islebe et al., 1996; Kennett et al., 2012; Medina-Elizalde and Rohling, 2012). Opposing views on geographical determinism are ongoing in scholarly discussions, and it seems clear as a general consensus that the rise and fall of Maya culture is multifactorial. The periods of Maya cultural development are based on archaeology and are usually divided into Archaic (7000-2000 before Christ [BC];
Voorhies, 1996), Preclassic (2000 BC-250 AD), Classic (250-900 AD), and Postclassic and Contact periods (900-1500 AD; Coe, 1993; Webster, 2002; Dunning et al., 2015). This subdivision does not necessarily reflect environmental or climatic change in each period.

Influence of Maya culture on the environment was reflected mainly in land cover changes, including deforestation in a broad sense, although there is ongoing discussion on the extent and relevance leading to culture demise and political breakdown (Aimers, 2007). This discussion includes different views, ranging from widespread forest reduction causing increasing aridity (Oglesby et al., 2010; Cook et al., 2012) to minimal forest cover loss due to adequate forest management (Ford and Nigh, 2009, 2016) and regional limited deforestation (Carrillo-Bastos et al., 2012), depending on the cultural period and climatic conditions. Climate variability is a key factor, mainly helping to explain precipitation variability in the Maya lowlands (Hodell et al., 1995; Dahlin, 2002; Medina-Elizalde and Rohling, 2012; Carrillo-Bastos et al., 2013; Douglas et al., 2016). The ancient Maya culture had profound knowledge of agriculture and forest management, and archaeological studies (Fedick, 2003) have shown transformation of wetlands for agricultural purposes with specific drainage channels. Others studies described the construction of terraces to reduce erosion and foster agricultural production (Dunning and Beach, 2000). Forest recovery after agricultural practices and climatic impact have shown that primary vegetation has a cycle of nearly 80 years (Mueller et al., 2010), and ancient Maya had a well-developed agroforestry system (Ford and Nigh, 2009).

In this paper we summarize available published data on fossil maize (Zea mays L.) in pollen records from the Yucatán Peninsula, showing the first use of maize in agriculture, and the relationship with environmental and climatic change. Fossil pollen of corn (Z. mays) is an excellent proxy for human impact, as its presence provides a direct link between Maya culture and agricultural activities (Islebe and Leyden, 2006; Holst et al., 2007). 


\section{Environmental setting}

\subsection{GLIMATE}

The climate of the Yucatán Peninsula is of a seasonal nature. There are mainly two distinct seasons. The rainy season between May and November and the dry season between December and April define the annual precipitation distribution. During the winter months (December March) arctic air incursions known locally as nortes can bring additional precipitation to the Yucatán Peninsula (Torrescano-Valle and Folan, 2015). The intra-annual displacement of the Intertropical Convergence Zone determines the seasonality of the precipitation (Haug et al., 2001, 2003; Méndez and Magaña, 2010). Additionally, there are differences across the region. The north zone has an annual precipitation between 600 and 900 $\mathrm{mm}$, while in the south it is between 900 and 1400 $\mathrm{mm}$. There is also a moisture gradient between the east and west coast, being the eastern coast of the Yucatán Peninsula influenced by jet streams providing humid air during the rainy season.

\subsection{VEGETATION}

The dominant vegetation type is seasonal dry tropical forest, but a variety of forest types and other vegetation types exist on the Yucatán Peninsula, such as mangroves, among other (Miranda, 1958). Seasonal dry tropical forest is the dominant vegetation type. High evergreen forest, with canopy greater than $30 \mathrm{~m}$, can be found in the southern Yucatán Peninsula, northern Guatemala, and Belize.

\section{Methods}

Published results on Zea mays (corn) occurrence in the Yucatán Peninsula were reviewed. A complete list of sites, with their respective radiocarbon age, and calibrated ages are listed in Table 1. Original calibrated ages from cited studies were accepted. A map was elaborated of sediment cores where $Z$. mays was found (Figure 1). Seven sites with a total of 57 samples of Zea mays of the Yucatán Peninsula were used to summarize pollen and ancient Maya cultural periods (Figure 2).

Table 1. List of sites recording Zea mays in Belize, Guatemala and México. Dates are original data.

\begin{tabular}{|c|c|c|}
\hline & Site & Oldest recorded date \\
\hline \multicolumn{3}{|l|}{ México } \\
\hline Carrillo-Bastos et al . 2010 & Tzib & 3500 cal yr BP \\
\hline Aragón-Moreno et al . 2012 & Ría Lagartos & 3600 cal yr BP \\
\hline Gutiérrez-Ayala et al . 2012 & Petenes & 2079 cal yr BP \\
\hline Carrillo-Bastos et al . 2013 & Ría Lagartos & 3840 cal yr BP \\
\hline Torrescano-Valle and Islebe, 2015 & Silvituc & 4100 cal yr BP \\
\hline Leyden et al. 1998 & Cobá & 2850 cal yr BP \\
\hline Leyden et al. 1996 & San José Chulchacá & $1180 \mathrm{AD}$ \\
\hline \multicolumn{3}{|l|}{ Guatemala } \\
\hline Islebe et al. 1996 & Petén Itzá & 2000 cal yr BP \\
\hline Mueller et al. 2009 & Petén Itzá & 3000 cal yr BP \\
\hline Wahl et al. 2014 & Puerto Arturo & 4600 cal yr BP \\
\hline Wahl et al. 2013 & Holmul & 3330 cal yr BP \\
\hline Wahl et al. 2007 & El Mirador & 4650 cal yr BP \\
\hline \multicolumn{3}{|l|}{ Belize } \\
\hline Jones et al. 1994 & Colha & 4500 cal yr BP \\
\hline Pohl et al. 1996 & Cobweb & 5000 cal yr BP \\
\hline Rushton et al. 2012 & Lamanai & 3650 cal yr BP \\
\hline
\end{tabular}



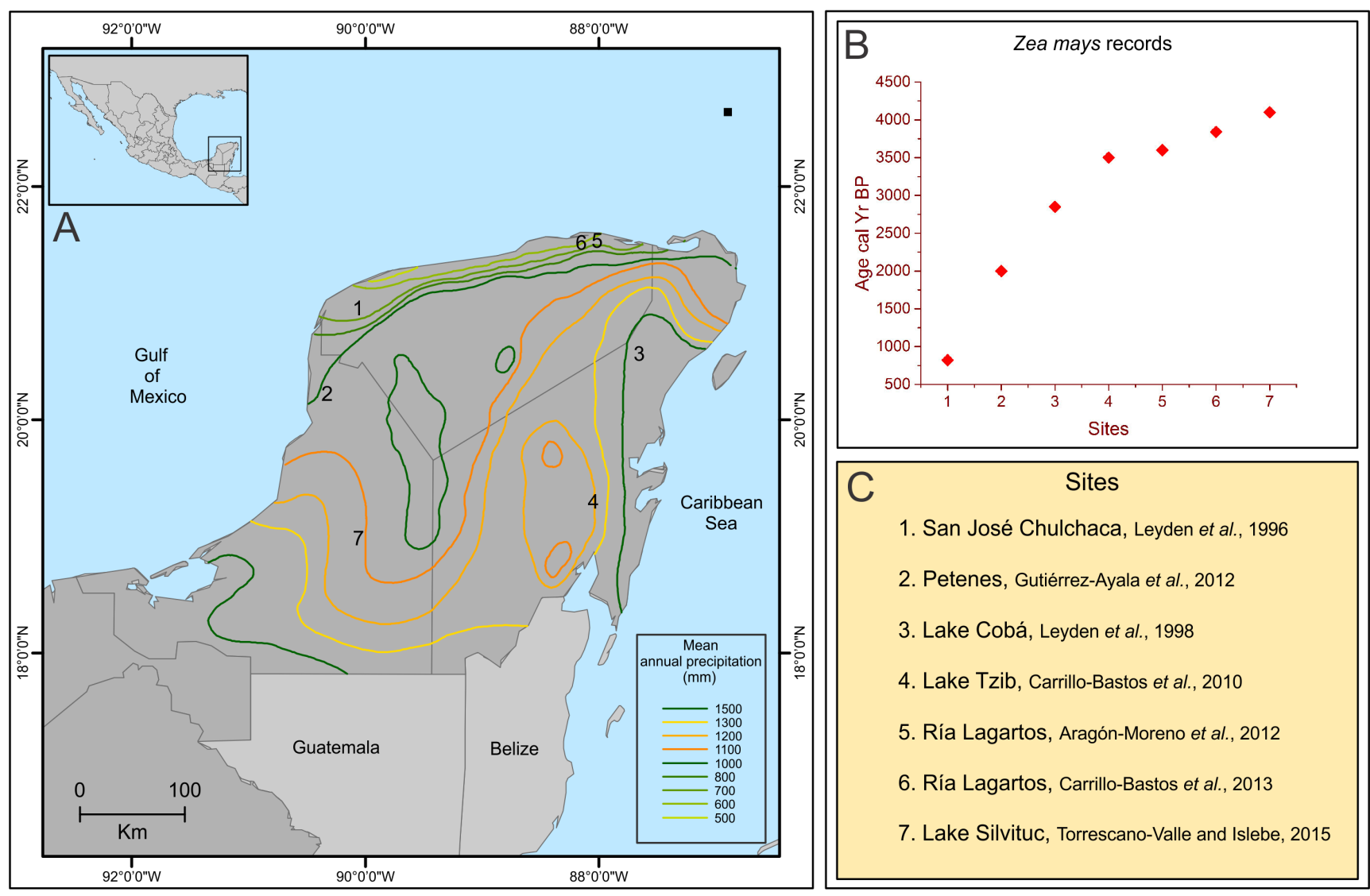

Figure 1 A) Geographical position of the Yucatán Peninsula with localities of sites. B) Zea mays records related to age and sites. C) Numbered sites with name and authors.

\section{Results and discussion}

For the Yucatán Peninsula, the oldest maize pollen grain comes from Cob swamp (Belize), and is dated at 3360 BC (Pohl et al., 1996). From northern Guatemala, Wahl et al. (2006, 2013, 2014) gave ages of first maize pollen between 2600 and 2300 BC. From the Mexican part of Yucatán Peninsula the oldest maize pollen evidence comes from Lake Silvituc and is dated at $2100 \mathrm{BC}$ (Torrescano-Valle and Islebe, 2015). From the northern part of the Yucatán Peninsula, the first recorded corn pollen has an estimated age of 1800 BC (Aragón-Moreno et al., 2012; Carrillo-Bastos et al., 2013). From the central region of the Yucatán Peninsula, Z mays pollen is dated at $1500 \mathrm{BC}$ (Carrillo-Bastos et al., 2010). From Lamanai, in northern Belize, an estimated age of $1600 \mathrm{BC}$ was given by Rushton et al. (2013) for first Z. mays appearance. Different studies have made relevant contributions on the origin and domestication of corn (Matsuoka et al., 2002; Doebley, 2004; Sluyter and Domínguez, 2006; Piperno et al., 2009). Paleoecological and genetic evidence have identified teosinte (Zea mays ssp. parviglumis and ssp. mexicana) as the most important ancestor of corn. This allowed detection of the highlands of Oaxaca and Guerrero (Holst et al., 2007) as the center of domestication, although pollen grain size might be insufficient to separate teosinte from corn. Evidence of early fossils of domesticated maize was presented by Piperno et al. (2009) with starch grains of phytoliths in the Rio Balsas valley between 9000 and 8600 calibrated years Before Present (cal yr BP). After maize 


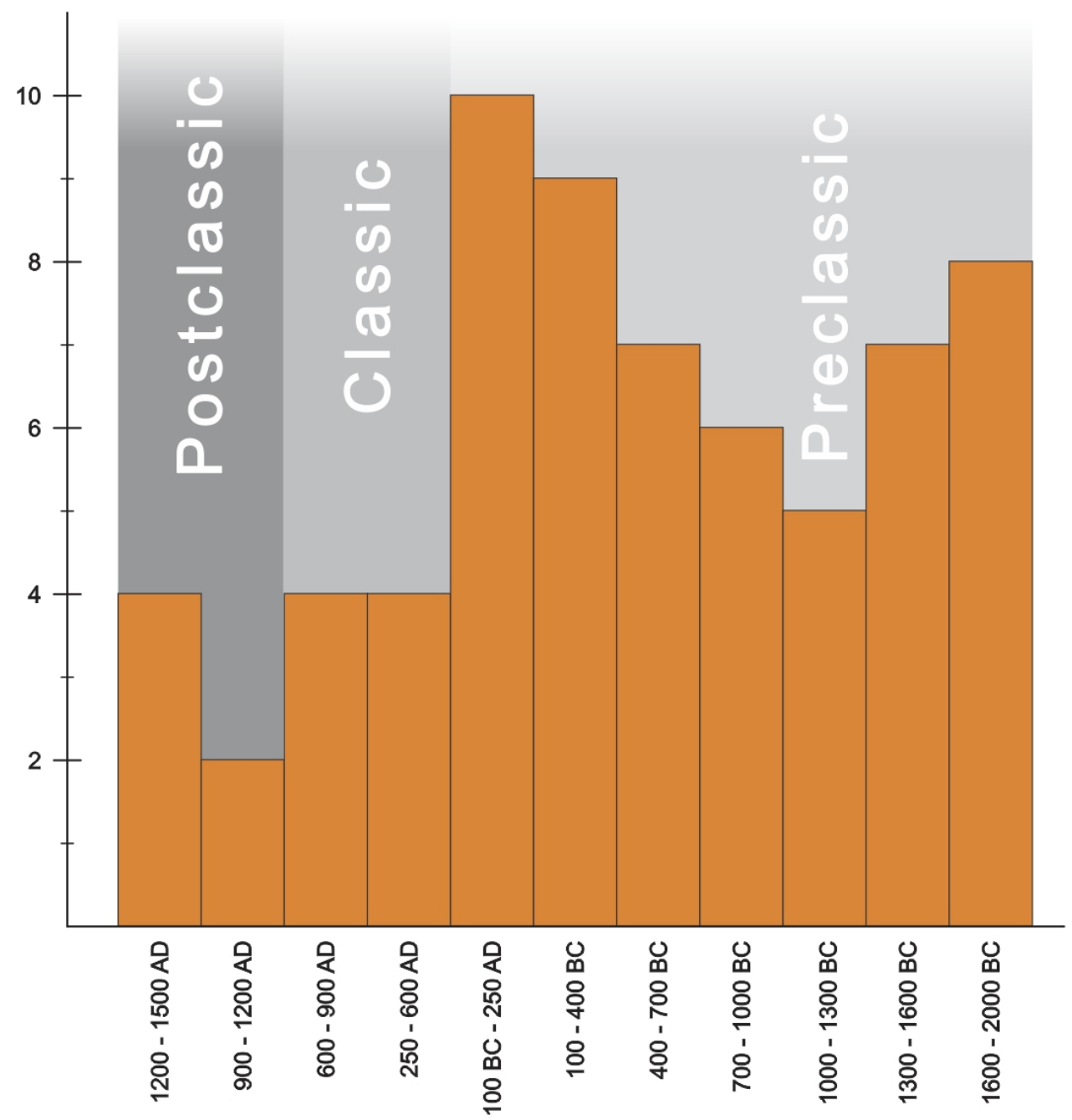

Figure 2 Zea mays presence in pollen records of the Yucatán Peninsula grouped according to Maya cultural periods.

was domesticated it spread into Central America around $7800 \mathrm{cal}$ yr BP (Piperno, 2011). The presence of fossil corn pollen in southern Mexico (Voorhies, 1996) is direct evidence of the use of corn since 4000 BC. For additional information on the geographical spread of corn we refer to Staller et al. (2009).

\subsection{IMPACT ON LANDSGAPE}

Reduction of forest cover combined with increase taxa indicating disturbance, and the presence of Zea mays pollen, has been used as an indicator of change in the landscape and/or induced change by climatic factors (Wiseman, 1978; Leyden, 2002). Other research included the importance of wetlands as suitable habitat for agriculture (Beach et al., 2008; Luzzadder-Beach et al., 2012). Other indicative pollen taxa that imply change in vegetation cover include Poaceae, Asteraceae, Cucurbitaceae, and Malvaceae, among others disturbance taxa (Wiseman, 1978; Islebe et al., 1996; Leyden et al., 1998), which generally appear before and after corn pollen records in many pollen diagrams. Slash and burn agriculture, different forms of agroforestry, and forestry harvesting were main 
agricultural activities. The sustainability of those activities is under academic scrutiny (Demarest, 2004; Ford and Nigh, 2009; Lentz et al., 2014, 2015; Douglas et al., 2016). Pohl et al. (1996) reported a strong deforestation around $2500 \mathrm{BC}$ in northern Belize, which could also be interpreted as a regional drought signal (Torrescano-Valle and Islebe, 2006; Mueller et al., 2009; Carrillo-Bastos et al., 2010). The drying signal around $3500 \mathrm{cal} \mathrm{yr}$ BP reported by Mueller et al. (2009) agrees with large regional drying trends from Cariaco Basin, Venezuela (Haug et al., 2001); Haiti (Hodell et al., 1991); Lake Valencia, Venezuela (Curtis et al., 1999); and from several lakes of the African tropics (Gasse, 2000). Intensified farming activities are dated between 1500 and 1300 BC with increased presence of corn in northern Belize (Pohl et al., 1996; Rushton et al., 2013). From the northern part of the Yucatán Peninsula, a similar pattern of climatic drying is observed after 3500 cal yr BP (Aragón-Moreno et al., 2012; Gutiérrez-Ayala et al., 2012). Z. mays was recorded in near-coastal lake sediments with an interpolated age of 1900 BC (Aragón-Moreno et al., 2012; Carrillo-Bastos et al., 2013). Changes in nearby coastal mangrove composition, mainly the turnover of species composition from Rhizophora mangle L. to dominant Conocarpus erectus L., with reduced pollen representation of forest taxa is indicative of a drying trend in the northern part of the Yucatán Peninsula (Aragón-Moreno et al., 2012; Carrillo-Bastos et al., 2013). The trend toward drier conditions had a few short phases of increased precipitation, but the terminal Preclassic period experienced increasing corn agriculture with drier climatic conditions (Figure 2). The terminal Preclassic drought and its subsequent population abandonment (150-250 $\mathrm{AD})$ were strong enough to cause the end of $z$. mays agriculture in the northern and driest parts of the Yucatán Peninsula (Carrillo-Bastos et al., 2013). In the middle Classic, corn appeared again in the sedimentary records.

The intensity and geographical extension of forest reduction is under discussion, due to differences in interpretation of paleoecological proxies (Ansel- metti et al., 2007; Carrillo-Bastos et al., 2012; Cook et al., 2012; Taylor et al., 2012; Dunning et al., 2015; Douglas et al., 2016).

Cook et al. (2012) considered that human induced deforestation led to an increased reduction in precipitation, which could have strengthened the natural drying trend during the late Classic period, and eventually led to the Maya collapse. Carrillo-Bastos et al. (2012), based on reconstructing the geographical distribution, its precipitation regime, and change of the most dominant vegetation type (the semi-evergreen forest) of the Yucatán Peninsula, found that deforestation was never complete. Some areas suffered from a higher deforestation rate than others, probably due to higher population densities and agricultural requirements of nearby population centers. The northern Yucatán Peninsula showed with a lower precipitation regime at $550 \mathrm{BC}$ with this geographical information system approach and precipitation reduction did not affect in a uniform manner due to geographical differences of precipitation regimes. At $450 \mathrm{AD}$ a widespread forest reduction can be observed, but no complete deforestation associated to intensified agriculture or amplified climatic change at this period (Carrillo-Bastos et al., 2012). Many forested areas switched to a more open character, and open vegetation types were most similar to savanna type vegetation, like at present in some parts of the central peninsula. In the central Yucatán Peninsula, two records provide evidence of fossil Z. mays, namely in the Lake Cobá record (Leyden et al., 1998) and a core from Lake Tzib (Carrillo-Bastos et al., 2010). Fossil pollen of corn was found at Cobá at $850 \mathrm{BC}$, and at Lake Tzib around 1500 BC. Anselmetti et al. (2007), based on a soil erosion study of Lake Salpetén, northern Guatemala, found that intense soil erosion layers (like Maya clay) occurred after initial land clearance in the early Preclassic and later (Rosenmeier et al., 2002), while in lakes from the Yucatán Peninsula, conspicuous erosion horizons are not observed. Figure 2 summarizes the number of sites with corn and its relative variation with cultural periods. Fossil pollen data agree with 
paleocological records and the cultural decline of ancient Maya culture (900-1200 AD) is shown by less fossil corn presence.

\subsection{ASSOGIATED TAXA TO Zea mays IN POLLEN RECORDS}

Other fossil pollen taxa that appear together with Zea mays in sediment cores mainly indicate forest disturbance caused by human activity or natural catastrophic events, like hurricanes or extensive fires (Islebe et al., 2001; Mueller et al., 2009). Other economical taxa that are recorded include $\mathrm{Cu}$ curbita (Pohl et al., 1996) and Gossypium (Wendel et al., 2010), which has been domesticated in the Yucatán Peninsula. Several paleoecological studies have shown similar results of taxa indicating disturbance due to land use change, mostly Cecropia peltata L., Croton sp., Acacia sp., Asteraceae, Solanaceae (Capsicum), Convolvulaceae, Malvaceae, Poaceae, and Chenopodiaceae-Amaranthaceae (Torrescano-Valle and Islebe, 2015). Species of the previously mentioned taxa include weeds (e.g., Chenopodiaceae-Amaranthaceae), fast growing herbaceous species (like Asteraceae, Convolvulaceae, Malvaceae). And pioneer trees and shrubs of early successional stages after forest disturbance (like Cecropia, Croton, Solanaceae, Acacia, and other members of the legume family) described by Nigh (2008), and Varela Scherrer and Trabanino (2016). Additionally, charred particles increase in pollen records with the presence of Z mays (Aragón-Moreno et al., 2012).

\section{Conclusions}

The research line we have adopted offers relevant information on the establishment of early agriculture in the Yucatán Peninsula. The relevance goes beyond the oldest record. Multiproxy environmental studies and interdisciplinary research aim at consistent chronologies of fossil evidence, and to include robust quantitative tools to establish a clear concept about the relation human and environment.
The concepts of Paleoanthropocene or Mayacene (Beach et al., 2015) seem attractive for the Yucatán Peninsula and northern Mesoamerica, considering the strong link between, climate, and environment and ancient Maya culture. The oldest corn record comes from northern Belize and is dated at 3300 BC. Several pollen records from Belize, Guatemala, and the Yucatán Peninsula present early fossil corn records between 1500 and 3000 BC. Temporal variability of corn appearance is due to different occupational histories of the area, different water availability, and differential fossil pollen preservation. Climate driven deforestation can be observed in many records around $3500 \mathrm{cal}$ yr BP, with a clear reduction of arboreal taxa and increase of taxa indicating disturbance or land use change. Human driven deforestation is related in some areas to Maya agriculture, shown by high soil erosion rates in some areas, although not recorded in most lakes of the Yucatán Peninsula. Finally, we conclude that Z. mays is an excellent indicator and proxy of the beginning of the (paleo) Anthropocene in the Yucatán Peninsula.

\section{Acknowledgements}

CONACyT is acknowledged for funding the projects Variabilidad climática y paleoecologia de los últimos 1500 años del sureste de México, Sinopsis paleo-actuo ecológica de las selvas de Quintana Roo, and Reconstrucción de Paleoambientes y Modelación Climática de la región oeste de la Península de Tucatán. Helpful comments of Ligia E. Urrego, one anonymous reviewer and the editors are acknowledged.

\section{References}

Aimers, J.J., 2007, What Maya Collapse? Terminal Classic Variation in the Maya Lowlands: Journal of Archaeological Research, 15, 329-377. 
Anselmetti, F.S., Hodell, D.A., Ariztegui, D., Brenner, M., Rosenmeier, M.F., 2007, Quantification of soil erosion rates related to ancient Maya deforestation: Geology, 35(10), 915-918.

Aragón-Moreno, A.A., Islebe, G.A., TorrescanoValle, N., 2012, A - 3800 yr high resolution record of vegetation and climate change on the north coast of the Yucatan peninsula: Review of Palaeobotany and Palynology, 178, 35-42.

Beach, T., Luzzadder-Beach, S., Dunning, N., Cook, D., 2008, Human and impacts on fluvial karst depressions of the Maya Lowlands: Geomorphology, 101, 308-331.

Beach, T., Luzzadder-Beach, S., Cook, D., Dunning, N., Kennett, D.J., Krause, S., Terry, R., Trein, D., Valdez, F., 2015, Ancient Maya Impacts on the Earth's Surface: An Early Anthropocene Analog? Quaternary Science Reviews, 124, 1-30.

Carrillo-Bastos., A., Islebe, G.A., TorrescanoValle, N., González, N.E., 2010, Holocene vegetation and climate history of central Quintana Roo, Mexico: Review of Palaeobotany and Palynology, 160, 189-196. Carrillo-Bastos, A., Islebe, G.A., TorrescanoValle, N., 2012, Geospatial Analysis of Pollen Records from the Yucatán Peninsula, Mexico: Vegetation History and Archaeobotany, 21, 429-37.

Carrillo-Bastos, A., Islebe, G.A., TorrescanoValle, N., 2013, 3800 years of quantitative precipitation reconstruction from the northwest Yucatan peninsula: Plos One, 8, e84333.

Coe, M., 1993, The Maya: London, Thames and Hudson, 224 p.

Cook, B.I., Anchukaitis, K.J., Kaplan, J.O., Puma, M.J., Kelley, M., Gueyffier, D., 2012, PreColumbian deforestation as an amplifier of drought: Geophysical Research Letters, 39, 1-5, DOI:10.1029/2012GL052565
Crutzen, P.C., Stoermer, E.F., 2000, The Anthropocene: Global Change Newsletter, 41, 17-18.

Curtis, J.H., Brenner, M., Hodell, D.A., 1999, Climate Change in the Lake Valencia Basin, Venezuela, 12600 yr BP to Present: The Holocene, 9, 609-619.

Dahlin, B.H., 2002, Climate change and the end of the Classic period in Yucatán: Resolving a paradox: Ancient Mesoamerica, 13(2), 327-340.

DeGlerk, F.A.J., Chazdon, R., Holl, K.D., Milder, J.C., Finegan, B., Martinez-Salinas, A., Imbach, P., Canet, L., Ramos, Z., 2010, Biodiversity conservation on humanmodified landscapes of Mesoamerica: Past, present and future: Biological Conservation, 143(10), 2301-2313.

Demarest, A.A., 2004, Ancient Maya: The Rise and Fall of a Rainforest Civilization: Cambridge, UK, Cambridge University Press, 377 p.

Doebley, J., 2004, The Genetics of Maize Evolution: Annual Review of Genetics, 38, 37-59.

Douglas, P.M.J., Demarest, A., Brenner, M., Canuto, M.A., 2016, Impacts of Climate on the Collapse of Lowland Maya Civilization: Annual Review of Earth and Planetary Sciences, 44, 613-645.

Dunning, N., Beach, T., 2000, Stability and Instability in Prehispanic Maya Landscapes, in Lentz, D.L. (Ed), Imperfect Balance: Landscape transformations in the Precolumbian Americas: New York, Columbia University Press, 179-202.

Dunning, N.P., Beach, T.P., Luzzadder-Beach, S., 2012, Kax and kol: Collapse and resilience in lowland Maya civilization: Proceedings of the National Academy of Sciences, 109(10), 3652-3657. 
Dunning, N.P., McCane, C., Swinney, T., Purtill, M., Sparks, J., Mann, A., McCool, J., Ivenso, C., 2015, Geoarchaeological Investigations in Mesoamerica Move into the $21^{\text {st }}$ Century: A Review: Geoarchaeology, 30, 167-199.

Fedick, S.L., 2003, Archaeological Evidence for Ancient and Historic Resource Use Associated with the El Edén Wetland, Northern Quintana Roo, Mexico, in GómezPompa, A., Allen, M.F., Fedick, S.L., Jiménez-Osornio, J.J. (Eds), The Lowland Maya Area: Three Millennia at the HumanWildland Interface: Binghamton, NY, Food Products Press (an imprint of The Haworth Press), 339-359.

Fedick, S., 2010, The Maya Forest: Destroyed or Cultivated by the ancient Maya?: Proceedings of the National Academy of Sciences, 107(3), 953-954.

Foley, S.F., Gronenborn, D., Andreae, M.O., Kadereit, J.W., Esper, J., Scholz, D., Pöschl, U., Jacob, D.E., Schöne, B.R., Schreg, R., Vött, A., Jordan, D., Lelieveld, J., Weller, C.G., Alt, K.W., Gaudzinski-Windheuser, S., Bruhn, K.C., Tost, H., Sirocko, F., Grutzen, P.J., 2013, The Palaeoanthropocene - The beginnings of anthropogenic environmental change: Anthropocene, 3, 83-88.

Ford, A., Nigh, R., 2009, Origins of the Maya forest garden: Maya resource management: Journal of Ethnobiology, 28, 213-216.

Ford, A., Nigh, R., 2016, The Maya forest garden: eight millennia of sustainable cultivation of the tropical woodlands: Routledge, Left Coast Press, 260 p.

Gasse, F., 2000, Hydrological Changes in the African Tropics since the Last Glacial Maximum: Quaternary Science Reviews, 19, 189-211.

Gutiérrez-Ayala, L.V., Torrescano-Valle, N., Islebe, G.A., 2012, Reconstruction paleoambiental del Holoceno tardio de la reserva Los Petenes, Península de Yucatán, México: Revista Mexicana de Ciencias Geológicas, 29, 749-763.
Haug, G.H., Hughen, K.A., Sigman, D.M., Peterson, L.C., Röhl, U., 2001, Southward Migration of the Intertropical Convergence Zone Through the Holocene: Science, 293, 1304-1308.

Haug, G.H., Günther, D., Peterson, L.C., Sigman, D.M., Hughen, K.A., Aeschlimann, B., 2003, Climate and the Collapse of Maya Civilization: Science, 299, 1731-1735.

Hodell, D.A., Curtis, J.H., Jones, G.A., HigueraGundy, A., Brenner, M., Binford, M.W., Dorsey, K.T., 1991, Reconstruction of Caribbean Climate Change over the Past 10, 500 Years: Nature, 352, 790-793.

Hodell, D.A., Curtis, J.H., Brenner, M., 1995, Possible role of climate in the collapse of Classic Maya civilization: Nature, 375, 391-394.

Holst, I., Moreno, J. E., Piperno, D., 2007, Identification of teosinte, maize, and Tripsacum in Mesoamerica by using pollen, starch grains, and phytoliths: Proceedings of the National Academy of Sciences, 104, 17608-17613.

Islebe, G.A., Hooghiemstra, H., Brenner, M., Curtis, J.H., Hodell, D.A., 1996, A Holocene vegetation history from lowland Guatemala: The Holocene, 6(3), 265-271.

Islebe, G.A., Villanueva-Gutiérrez, R., SánchezSánchez, O., 2001, Relación lluvia de polenvegetación en selvas de Quintana Roo: Boletín de La Sociedad Botánica de México, 69, 31-38.

Islebe, G.A., Leyden, B.W., 2006, La vegetación de Guatemala durante el Pleistoceno terminal y Holoceno, in Cano, E. (ed.), Biodiversidad de Guatemala: Guatemala, Universidad del Valle de Guatemala, 15-23.

Islebe, G.A., Sánchez-Sánchez, O., ValdézHernández, M., Weissenberger, H., 2015, Distribution of vegetation types, in Islebe, G.A., Calmé, S., León-Cortes, L., Schmook, B. (eds.), Biodiversity and Conservation of the Yucatán Peninsula: Switzerland, Springer International Publishing, 39-53. 
Kennett, D.J., Breitenbach, S.F.M., Aquino, V.V., Asmerom, Y., Awe, J., Baldini, J.U.L., Bartlein, P., Culleton, B.J., Ebert, C., Jazwa, C., Macri, M.J., Marwan, N., Polyak, V., Prufer, K.M., Ridley, H.E., Sodemann, H., Winterhalder, B., Haug, G.H., 2012, Development and Disintegration of Maya Political Systems in Response to Climate Change: Science, 338, 788-791.

Lentz, D.L., Dunning, N.P., Scarborough, V.L., Magee, K.S., Thompson, K.M., Weaver, E., Carr, C., Terry, R.E., Islebe, G.A., Tankersley, K.B., Grazioso-Sierra, L., Jones, J.G., Buttles, P., Valdez, F., Ramos-Hernandez, C.E., 2014, Forests, fields, and the edge of sustainability at the ancient Maya city of Tikal: Proceedings of the National Academy of Sciences, 111, 18513-18518.

Lentz, D.L., Magee, K., Weaver, E., Jones, J.G., Tankersley, K.B., Hood, A., Islebe, G.A., Ramos-Hernandez, C.E., Dunning, N.P., 2015, Agroforestry and Agricultural Practices of the Ancient Maya at Tikal, in Lentz, D.L., Dunning, N.P., Scarborough, V. (eds.), Tikal, paleoecology of an ancient Maya City: Cambridge, Cambridge University Press, 152-186.

Leyden, B.W., Brenner, M., Dahlin, B.H., 1998, Cultural and climatic history of Coba, a lowland Maya City in Quintana Roo, Mexico: Quaternary Research, 49, 111-122. Leyden, B.W., 2002, Pollen evidence for climatic variability and cultural disturbance in the Maya lowlands: Ancient Mesoamerica, 13, 85-101.

Luzzadder-Beach, S., Beach, T.P., Dunning, N.P., 2012, Wetland fields as mirrors of drought and the Maya abandonment: Proceedings of the National Academy of Sciences, 109, 3646-3651.

Matsuoka, Y., Vigouroux, Y., Goodman, M.M., Sanchez-G., J., Buckler, E., Doebley, J., 2002, A Single Domestication for Maize Shown by Multilocus Microsatellite Genotyping: Proceedings of the National Academy of Sciences, 99, 6080-6084.

McNeil, G.L., Burney, D.A., Pigott Burney, L. 2010, Evidence disputing deforestation as the cause for the collapse of the ancient Maya polity of Copan, Honduras: Proceedings of the National Academy of Sciences 107, 1017-1022.

McNeil, C.L., 2012, Deforestation, agroforestry, and sustainable land management practices among the Classic period Maya: Quaternary International, 249, 19-30

Medina-Elizalde, M., Rohling, E.J., 2012, Collapse of Classic Maya civilization related to modest reduction in precipitation: Science, 335, 956-959.

Méndez, M., Magaña, V., 2010, Regional aspects of prolonged meteorological droughts over Mexico: Journal of Climate, 23, 1175-1188.

Miranda, F., 1958, Estudios acerca de la vegetación, in Beltrán, E. (ed), Los recursos naturales del sureste y su aprovechamiento: México, Instituto Mexicano de Recursos Naturales Renovables, 215-271.

Mueller, A.D., Islebe, G.A., Hillesheim, M.B., Grzesik, D.A., Anselmetti, F.S., Ariztegui, D., Brenner, M., Curtis, J.H., Hodell, D.A., Venz, K.A., 2009, Climate drying and associated forest decline in the lowlands of northern Guatemala during the late Holocene: Quaternary Research, 71, 133-141.

Mueller, A.D., Islebe, G.A., Anselmetti, F.S., Ariztegui, D., Brenner, M., Hodell, D.A., Hajdas, I., Hamann, Y., Haug, G.H., Kennett, D.J., 2010. Recovery of the forest ecosystem in the tropical lowlands of northern Guatemala after disintegration of Classic Maya polities: Geology, 38, 523-526. Nigh, R., 2008, Trees, Fire And Farmers: Making Woods And Soil In The Maya Forest: Journal of Ethnobiology, 28, 231-243. 
Oglesby, R.J., Sever, T.L., Saturno, W., Erickson, D.J., Srikishen, J., 2010, Collapse of the Maya: Could deforestation have contributed?: Journal of Geophysical Research: Atmospheres, 115, D12106

Piperno, D.R., Ranere, A.J., Holst, I., Iriarte, J., Dickau, R., 2009, Starch grain and phytolith evidence for early ninth millennium B.P. maize from the Central Balsas River Valley, Mexico: Proceedings of the National Academy of Sciences, 106, 5019-5024.

Piperno, D.R., 2011, The Origins of Plant Cultivation and Domestication in the New World Tropics: Patterns, Process, and New Developments: Current Anthropology, 52, S453-S470.

Pohl, M.D., Pope, K.O., Jones, J.G., Jacob, J.S., Piperno, D.R., deFrance, S.D., Lentz, D.L., Gifford, J.A., Danforth, M.E., Josserand, J.K., 1996, Early Agriculture in the Maya Lowlands: Latin American Antiquity, 7, 355-72.

Rosenmeier, M.F., Hodell, D.A., Brenner, M., Curtis, J.H., Martin, J.B., Anselmetti, F.S., Ariztegui, D., Guilderson, T.P., 2002, Influence of vegetation change on watershed hydrology: implications for paleoclimatic interpretation of lacustrine $\delta^{18} \mathrm{O}$ records: Journal of Paleolimnology, 27, 117-131.

Rushton, E.A.C., Metcalfe, S.E., Whitney, B.S., 2013, A late-Holocene vegetation history from the Maya lowlands, Lamanai, Northern Belize: The Holocene, 23, 485-493.

Sluyter, A., Dominguez, G., 2006, Early Maize (Zea mays L.) Gultivation in Mexico: Dating Sedimentary Pollen Records and Its Implications: Proceedings of the National Academy of Sciences of the United States of America, 103, 1147-1151.

Staller, J.E., Tykot, R.H., Benz, B.F. (eds.), 2009, Histories of Maize: multidisciplinary approaches to the prehistory, linguistics, biogeography, domestication, and evolution of maize: Walnut Creek, California, Left Coast Press, 678 p.
Taylor, Z.P., Horn, S.P., Finkelstein, D.B., 2012, Maize pollen concentrations in neotropical lake sediments as an indicator of the scale prehistoric agriculture: The Holocene, 23, 78-84.

Torrescano-Valle, N., Islebe, G.A, 2006, Tropical forest and mangrove history from southeastern Mexico: a 5000 yr pollen record and implications for sea level rise: Vegetation History and Archaeobotany, 15, 191-195.

Torrescano-Valle, N., Folan, W.J., 2015, Physical Settings, Environmental History with an Outlook on Global Change, in Islebe, G.A., Calmé, S., León-Cortes, L., Schmook, B. (eds.), Biodiversity and Conservation of the Yucatán Peninsula: Switzerland, Springer International Publishing, 9-37.

Torrescano-Valle, N., Islebe, G.A., 2015, Holocene paleoecology, climate history and human influence in the southwestern Yucatan Peninsula: Review of Palaeobotany and Palynology, 217, 1-8.

Varela Scherrer, G.M., Trabanino, F., 2016, La cacería tradicional chol y tseltal en los acahuales de Palenque, Chiapas: implicaciones para la zooarqueología maya: Pueblos y fronteras, 11(22), 165-191.

Voorhies, B., 1996, The transformation from foraging to farming in lowland Mesoamerica, in Fedick, S. (ed.), The managed mosaic: Ancient Maya Agriculture and Resource Use: Salt Lake City, University of Utah Press, 17-29.

Wahl, D., Byrne, R., Schreiner, T., Hansen, R., 2006, Holocene vegetation change in the northern Peten and its implications for Maya prehistory: Quaternary Research, 65, 380-389.

Wahl, D., Estrada-Belli, F., Anderson, L., 2013, A 3400 year paleolimnological record of prehispanic human-environment interactions in the Holmul region of the southern Maya lowlands: Palaeogeography, Palaeoclimatology, Palaeoecology, 379, $17-31$. 
Wahl, D., Byrne, R., Anderson, L., 2014, An 8700 year paleoclimate reconstruction from the southern Maya lowlands: Quaternary Science Reviews, 103, 19-25.

Webster, D.L., 2002, The Fall of the Ancient Maya: Solving the Mystery of the Maya Collapse: New York, Thames and Hudson, $368 \mathrm{p}$.

Wendel, J.F., Brubaker, C.L., Seelanan, T., 2010, The origin and evolution of Gossypium, in Stewart,J. McD., Oosterhuis, D.M., Heitholt, J.J., Mauney, J.R. (eds.), Physiology of Cotton: Netherlands, Springer, 1-18.
Wiseman, F.M., 1978, Agricultural and Historical Ecology of the Maya lowlands, in Harrison, P.D., Turner II, B.L., Pre-Hispanic Maya agriculture: Albuquerque, University of New Mexico Press, 63-116. 